\title{
PENGARUH AROMATERAPI LAVENDER TERHADAP KECEMASAN IBU BERSALIN PADA PANDEMI COVID-19 DI PUSKESMAS I DENPASAR TIMUR
}

\author{
${ }^{1)}$ Ni Wayan Noviani, ${ }^{2)}$ Ni Luh Putu Citrawati, ${ }^{3)}$ Putu Savitri Astikasari \\ ${ }^{1)}$ Program Studi Diploma IV Kebidanan Politeknik Kesehatan Kartini Bali, ${ }^{2)}$ Puskesmas I Denpasar Timur, ${ }^{3)}$ Program \\ Studi Diploma III Kebidanan Politeknik Kesehatan Kartini Bali \\ E-mail : ${ }^{1)}$ novyfast@yahoo.com, ${ }^{2)}$ citranadhi76@ gmail.com, ${ }^{3)}$ astikasari15@ gmail.com
}

\section{Kata Kunci:}

Aromaterapi Lavender, Tingkat kecemasan, Ibu bersalin

\section{Keywords:}

Lavender aromatherapy, Anxiety levels, maternity

\section{Info Artikel}

Tanggal dikirim: 18-10-2021

Tanggal direvisi: 16-11-2021

Tanggal diterima: 23-1-2022 DOI Artikel:

10.36341/jomis.v6i1.2142

Creative Commons Attribution-

NonCommercial-ShareAlike 4.0 International License.

\begin{abstract}
ABSTRAK
Bencana Non alam yang disebabkan oleh virus Covid 19 yang sedang melanda Indonesia saat ini menjadi salah satu faktor yang dapat menimbulkan kecemasan pada ibu yang akan menghadapi persalinan. Kecemasan dalam persalinan adalah kondisi umum bagi wanita hamil. Ibu yang mengalami kecemasan pada proses persalinan maka dapat menyebabkan terjadikan keadaan yang patologis. Penanganan alternatif untuk mengurangi rasa cemas pada ibu bersalin adalah dengan menggunakan aromaterapi. Hasil Penelitian ini bertujuan untuk mengetahui pengaruh aromaterapi lavender terhadap kecemasan ibu bersalin pada pandemi covid-19. Jenis penelitian ini adalah quasi eksperimen dengan one group pretest-posttes without control. Populasi dalam penelitian ini adalah seluruh ibu yang bersalin di wilayah kerja Puskesmaa I Denpasar Timur dengan sampel berjumlah 20 ibu bersalin yang sesuai kriteria inklusi dan diambil secara purposive sampling. Alat pengumpulan data yang digunakan adalah kuisioner DASS. Hasil penelitian ini menggunakan uji paired t-test menunjukkan bahwa ada perbedaan yang bermakna antara tingkat kecemasan sebelum diberikan aromaterapi dan setelah diberikan aromaterapi dilihat dari hasil p-value $<0.05$.
\end{abstract}

\begin{abstract}
Non-natural disasters caused by the Covid 19 virus that is currently engulfing Indonesia is currently one of the factors that can cause anxiety in mothers who will face childbirth. Anxiety in childbirth is a common condition for pregnant women. Mothers who experience anxiety in the labor process can cause pathological conditions. An alternative treatment to reduce anxiety in maternity mothers is to use aromatherapy. The results of this study aim to find out the effect of lavender aromatherapy on the anxiety of maternity mothers in the covid-19 pandemic. This type of research is a quasi experiment with one group pretest-posttes without control. The population in this study was all mothers who were pregnant in the working area of Puskesmaa I Denpasar Timur with a sample of 20 maternity mothers who fit the criteria of inclusion and taken purposive sampling. The data collection tool used is a DASS questionnaire. The results of this study using a paired t-test showed that there was a meaningful difference between the level of anxiety before being given aromatherapy and after being given aromatherapy judging from the p-value of $<0.05$.
\end{abstract}

\section{PENDAHULUAN}

Indonesia sedang menghadapi wabah bencana alam yaitu penyakit virus korona. Penyakit ini adalah penyakit menular yang disebabkan oleh virus SARS-CoV-2. Pemerintah menetapkan hal ini sebagai bencana nasional berdasarkan Keputusan Presiden Republik Indonesia Nomor 12 Tahun
2020 sebagai Bencana Nasional [1].

Angka Kematian Ibu (AKI) dan Angka Kematian Bayi (AKB) adalah tantangan terbesar dan perlu mendapatkan perhatian dalam situasi ini. Pemerintah telah mengeluarkan pedoman bagi ibu hamil, ibu bersalin, ibu nifas dan bayi baru lahir selama wabah ini berlangsung [1]. 
Pedoman ini merupakan panduan bagi pemberi layanan ibu hamil, ibu bersalin dan bayi baru lahir dalam memberikan pelayanan sesuai standar dalam masa social distancing. Prinsip - prinsip pencegahan covid-19 meliputi universal precaution. Pelayanan pada ibu bersalin yang dihimbau oleh pemerintah selama pandemic adalag sebagai berikut : rujukan terencana untuk hamil beresiko, ibu tetap bersalin di fasilitas pelayanan kesehatan, ibu dengan kasus Covid-19 akan ditatalaksana sesuai tatalaksana persalinan yang dikeluarkan oleh PP POGI [1].

Berdasarkan laporan WHO tahun 2017, sebesar 94\% dari semua kematian ibu terjadi di Negara berpenghasilan rendah dan menengah, $75 \%$ penyebabnya adalah perdarahan, infeksi, komplikasi persalinan, tekanan darah tinggi selama kehamilan [2]. Sehingga, wanita yang menghadapi persalinan memerlukan perhatian khusus oleh keluarga dan tenaga medis.

Persalinan adalah proses yang menyakitkan dan menegangkan namun persalinan dapat dialami dengan aman dan nyaman tanpa trauma. Persalinan adalah proses pengeluaran hasil konsepsi seperti janin plasenta dan cairan ketuan hidup ke dunia luar [3]. Persalinan adalah saat - saat yang paling ditunggu oleh ibu dan suami beserta keluarga. Setiap wanita menginginkan persalinan yang aman, nyaman dan lancar, namun tidak jarang proses persalinan menghadapi hambatan dan memerlukan penanganan untuk mengatasinya [4].

Persalinan normal adalah proses pengeluaran janin cukup bulan berkisar 37-42 minggu, lahir spontan dengan manifestasi belakang kepala yang berlangsung kurang lebih 18 jam tanpa komplikasi. Beberapa faktor yang mempengaruhi persalinan yaitu $5 \mathrm{P}$ (power, passenger, passage, provider dan psyche). Pada umumnya ibu akan mengalami gangguan psikologi saat bersalin [5].

Psyche atau Psikologi adalah salah satu faktor yang mempengaruhi kondisi bersalin. Ibu lazim merasa cemas dengan kehamilannya dan takut saat menghadapi persalinan. Kecemasan merupakan suatu kondisi yang normal dirasakan oleh semua orang merasa mengalami tekanan sehingga dapat menyebabkan masalah psikis[3].

Kecemasan ini akan muncul pada akhir kehamilan dan akan semakin meningkat menjelang persalinan diakibatkan oleh stigma yang muncul di lingkungan dan masyarakat tentang proses persalinan yang menyakitkan dan akan memunculkan trauma bagi wanita hamil. Kecemasan lain yang muncul menjelang bersalin yaitu kelancaran proses persalinan dan keadaan ibu dan bayi [6].

Kecemasan dipengaruhi oleh ebberapa faktor seperti usia ibu, tingkat pendidikan, dan paritas. Berdasarkan hasil penelitian yang dilakukan oleh Asri, et al 2014 tentang hubungan karakteristik ibu hamil Trimester III dengan tingkat kecemasan ibu dalam menghadapi persalinan [7]

Laporan dari Kemenkes RI menyebutkan, ibu hamil mengalami kecemasan di Indonesia hingga 379 juta ibu hamil, sedangkan di Pulau Sumatera sebanyak $355.873 \mathrm{ibu}$ hamil mengalami kecemasan menurut hasil penelitian Handayani pada tahun 2015. Penelitian lain menjelaskan tentang kecemasan salah satunya Priharyanti tahun 2019 ditemukan sebanyak 60\% responden ibu hamil trimester III di wilayah kerja puskesmas Mijen Kota Semarang menunjukkan tingkat 
kecemasan pada kategori sedang dan 20\% responden pada kategori ringan. Faktor faktor yang menjadi penyebab timbulnya kecemasan biasanya berhubungan dengan kondisi kesejahteraan ibu dan bayi yang akan dilahirkan, pengalaman keguguran, rasa aman dan nyaman selama kehamilan, penemuan jati dirinya dan dan persiapan menjadi orang orang tua, sikap memberi dan menerima kehamilan, keuangan keluarga, dukungan keluarga, support tenaga medis, usia ibu hamil, dukungan suami, tingkat persiapan personal ibu, pengalam traumatis ibu dan tingkat aktifitas [8].

Menurut Siallagan \& Lestari, 2018 melaporkan bahwa 28,7\% ibu hamil trimester III mengalami kecemasan. Kecemasan pada akhir kehamilan yang dialami oleh ibu disebabkan oleh rasa sakit atau rasa nyeri, proses persalinan serta keadaan bayi dan keadaan ibu selama proses persalinan. Apabila hal yang membuat kecemasan dibiarkan dapat berdampak buruk bahkan sampai membahayakan ibu dan bayinya [9].

Penanganan kecemasan yang dapat diberikan terdiri dari dua terapi yaitu terapi farmakologis/obat-obatan (anxiolytic) dan terapi non farmakologis/cara alami dengan psikoterapi (relaksasi). Penanganan tanpa mengunakan obat-obatan untuk mengurangi cemas pada ibu bersalin adalah dengan menggunkaan aromaterapi [10]. Selain itu menurut penelitian lain, Aromaterapi adalah salah satu cara dari jenis Complemenary and Alternative Medicine (CAM) yang banyak digunakan dengan menghirup uap atau penyerapan minyak kedalam kulit yang bermanfaat untuk mengobat dan mengurangi gejala fisik dan emosional [3]. Aromaterapi lavender tidak hanya dapat diberikan secara inhalasi namun juga dapat diberikan dengan pemijatan, berendam dan kompres. Terapi ini juga memiliki efek yang sama yaitu mengurangi gangguan psikis pada wanita bersalin [11].

Aromaterapi adalah pengobatan alternatif dengan bahan cair yang berasal dari tumbuh-tumbuhan yang mudah menguap biasa disebut minyak atsiri yang dapat mempengaruhi kesejahteraan fisik dan psikologis melalui emosi jiwa dan fungsi kognitif terjaga[10]. Minyak atsiri yang diekstrak dari tanaman lavender digunakan dalam aromaterapi untuk memberikan efek relaksasi, antidepresan dan sedatif bagi orang yang mengalami kesulitan tidur dan untuk meningkatkan perasaan, mengurangi kecemasan dan meningkatkan tingkat kewaspadaan. Senyawa polifenol yang terkandung dalam lavender memiliki manfaat sebagai antioksidan dan mengurangi penyakit jantung karena mengandung linalyl acetate dan linalool yang dapat memerikan efek relaksasi [6].

Penelitian Igarashi yang dilakukan Department Of Obstetrics And Gynecology Located In A Hospital In Kyoto (2015), menyatakan bahwa terdapat efek relaksasi dari minyak esensial lavender yang mengandung linalyl acetate atau linalool. Linalyl acetate atau linalool inilah yang dapat memperlancar pengeluaran hormone serotonin yang tersumbat. Artinya pemberian aromaterapi sangat efektif dalam menurunkan kecemasan menghadapi persalinan.

Berdasarkan latar belakang diatas peneliti ingin mengetahui pengaruh aromaterapi lavender terhadap kecemasan ibu bersalin pada pandemi covid-19 di Puskesmas I Denpasar Timur. 


\section{TINJAUAN PUSTAKA}

World Health Organization (WHO) menetapkan tentang virus corona atau yang biasa disebut dengan COVID 19 yang menjadi pandemic karena virus ini telah menyebar ke berbagai negara bahkan sudah mendunia. Coronavirus Disease 2019 (COVID-19) adalah penyakit menular yang disebabkan oleh Severe Acute Respiratory Syndrome Coronavirus 2 (SARS-CoV-2). WHO mengartikan pandemi sebagai suatu kondisi populasi pada dunia dan berpotensi menjadikan jatuh dan sakit. Pandemi sendiri adalah wabah yang berjangkit secara bersamaan dmana-mana yang menyebar luas [1].

Coronavirus adalah virus yang menyebabkan penyakit mulai dari gejala ringan sampai berat. Virus ini merupakan penyakit jenis virus baru yang belum pernah diidntifikasi sebelumnya pada manusia. Tanda dan gejala terinfeksi virus covid-19 seperti flu, demam, batuk dan sesak nafas. Masa inkubasi virus rata-rata 5-6 hari dengan masa inkubasi terpanjang adalah 14 hari. Selama pandemi covid-19, pelayanan yang diberikan bagi ibu bersalin harus sesuai dengan memperhatikan protokol-protokol penyebaran virus corona [1].

Persalinan normal adalah proses pengeluaran janin cukup bulan berkisar 37-42 minggu, lahir spontan dengan manifestasi belakang kepala yang berlangsung kurang lebih 18 jam tanpa komplikasi. Persalinan adalah bagian dari proses melahirkan sebagai respons terhadap kontraksi uterus, segmen bawah uterus teregang dan menipis, serviks berdilatasi, jalan lahir terbentuk dan bayi bergerak turun ke bawah melalui rongga panggul. Faktor - faktor yang mempengaruhi persalinan yaitu: (1) Power adalah kekuatan janin yang mendorong janin keluar. Kekuatan yang mendorong janin keluar dalam persalinan ialah his, kontraksi otot-otot perut, kontraksi diafragma dan aksi dari ligament, dengan kerja sama yang baik dan sempurna, (2) Passenger adalah faktor lain yang berpengaruh terhadap persalinan adalah faktor janin,yang meliputi sikap janin, letak janin, presentasi janin, bagian terbawah janin, dan posisi janin, (3) Psikologi atau psikis ibu bersalin sangat berpengaruh dari dukungan suami dan anggota keluarga yang lain untuk mendampingi ibu selama bersalin dan kelahiran anjurkan mereka berperan aktif dalam mendukung dan mendampingi langkah-langkah yang mungkin akan sangat membantu kenyamanan ibu, hargai keinginan ibu untuk didampingi, dapat membantu kenyamanan ibu, hargai keinginan ibu untuk didampingi [3].

Penelitian Burns et al., 2007 dilakukan di Inggris pada 8 ribu wanita hamil rentang waktu tahun 1990 sampai dengan 1998 menunjukan efek aromaterapi dalam mengurangi rasa sakit, rasa cemas, dan ketakutan saat persalinan. Dalam penelitian ini, $61 \%$ wanita hamil menggunakan lavender dan frankincare untuk mengurangi rasa takut dan cemas. Hal ini sejalan dengan penelitian yang dilakukan oleh Orgozali pada tahun 2013 yang menemukan aromaterapi lavender dapat mengurangi nyeri persalinan dan kecemasan pada ibu - ibu yang baru melahirkan Aromaterapi Lavender memiliki sifat sebagai anti kecemasan, penghilang rasa sakit dan membangkitkan suasana hati seseorang [12].

Lavender adalah salah satu aromaterapi yang paling populer untuk gangguan kecemasan atau bahasa Latin daro lavender adalah Lavandula angustifolia Miller atau Lavandula officinalis Chaix. Organisasi internasional, WHO, ESCOP, EMA menyepakati tanaman obat ini dapat 
diperuntukkan dalam menghilangkan stres, kegelisahan dan kecemasan [13]. Aromaterapi lavender adalah aromaterapi yang sangat direkomendasikan untuk mengatasai rasa gelisah, stres bahkan depresi.

Lamadah et al (2016) menemukan bahwa melakukan penghirupan minyak atsiri lavender dapat meningkatkan kesadaran dan mengurangi kecemasan [14]. Sejalan dengan yang dikemukakan oleh Istiqomah 2021, bahwa memberikan aromaterapi lavender dengan inhalasi memiliki pengaruh signifikan mengurangi tingkat kecemasan ibu bersalin [15].

Penelitian Igarashi yang dilakukan di Department Of Obstetrics And Gynecology Located In A Hospital In Kyoto pada tahun 2015 menunjukkan pengaruh relaksasi dari linalyl acetate atau linalool yang terkandung dalam minyak esensial lavender [6]. Linalyl acetate atau linalool yang dapat melancarkan hormone serotonin yang tersumbat [13]. Dapat disimpulkan bahwa aromaterapi sangat efektif dalam mengurangi kecemasan persalinan.

Penelitian dengan judul The Effect of Aromatherapy Massage Using Lavender Oil on the Level of Pain and Anxiety During Labour Among Primigravida Women dilakukan pada $60 \mathrm{ibu}$ bersalin dibagi kedalam dua kelompok, kelompok pertama diberikan pemijatan punggung ditambah 2 tetes esensial oil lavender yang diencerkan dalam $50 \mathrm{cc}$ minyak almond dan kelompok kedua hanya pemijatan punggung saja [14]. Hasil penelitian tersebut dilaporkan bahwa tingkat kecemasan pada kelompok pertama signifikan mengalami penurunan yaitu 36,33 dari 38,40 dibandingkan dengan kelompok kedua yaitu 44,07 dari 45,13 dari . Berdasarkan hasil statistik nilai $p$-value $<0,05$.
Berdasarkan dari hasil penelitian diatas yang telah dilakukan oleh peneliti sebelumnya bahwa aromaterapi lavender memiliki pengaruh terhadap tingkat kecemasan ibu bersalin.

\section{METODE}

Penelitian ini adalah penelitian dengan eksperimen semu dengan rancangan one group pretest - posttest without control. Pada penelitian ini, ibu bersalin pada fase aktif (pembukaan 4-10 $\mathrm{cm}$ ) sebelum diberikan aromaterapi lavender maka diukur terlebih dahulu tingkat kecemasannya dengan DASS. Jika telah didapatkan hasil pengukuran sebelum diberikan tindakan, selanjutnya ibu diberikan aromaterapi lavender. Setelah diberikan aromaterapi lavender, maka diukur kembali tingkat kecemasan ibu dengan menggunakan DASS.

Penelitian dilakukan selama 3 bulan dari bulan Juli-Oktober 2021, menggunakan sampel $20 \mathrm{ibu}$ bersalin yang sesuai dengan kriteria inklusi yaitu : ibu bersalin normal tanpa komplikasi, ibu dengan kecemasan, kehamilan aterm, ibu dengan paritas primipara dan multipara serta bersedia menjadi responden. Sedangkan kriteria eksklusi yaitu : ibu yang mengalami kedaruratan/komplikasi saat bersalin, ibu yang tidak dapat berkomunikasi dengan baik, ibu yang mengalami alergi terhadap minyak dan ibu yang menderita asma.

Teknik sampling yang digunakan purposive Sampling. Instrumen data dengan kuesioner DASS (Depression, Anxiety and Stess Scales) yang memuat 14 pertanyaan mengenai kecemasan. Analisis data univariat yang dilakukan untuk mendeskripsikan karakteristik dan variabel yang akan dianalisa dengan memasukkan semua variabel yang 
diteliti. Analisis bivariat dengan menggunakan uji Paired T-test.

HASIL DAN PEMBAHASAN

Tabel 1. Distribusi Frekuensi Karakteristik

Responden

\begin{tabular}{lcc}
\hline $\begin{array}{l}\text { Karakteristik } \\
\text { Responden }\end{array}$ & $\begin{array}{c}\text { Frekuensi } \\
(\mathbf{f})\end{array}$ & $\begin{array}{c}\text { Persentase } \\
(\%)\end{array}$ \\
\hline Umur & & \\
$<20$ th & 0 & 0 \\
$20-35$ th & 18 & 90 \\
$>35$ th & 2 & 10 \\
Pendidikan & & \\
Dasar & 2 & 10 \\
Menengah & 11 & 55 \\
Tinggi & 7 & 35 \\
Paritas & & \\
Primigravida & 3 & 15 \\
Multigravida & 17 & 85 \\
Grande & 0 & 0 \\
multigravida & & \\
& & \\
\hline
\end{tabular}

Berdasarkan tabel 1 pada data karakteristik responden didapatkan bahwa hampir seluruh responden $(90 \%)$ memiliki rentang umur 20-35 tahun, sebagian besar $(55 \%)$ responden memiliki pendidikan menengah dan hampir seluruhnya (85\%) responden merupakan kategori multigravida.

Tabel 2. Distribusi Frekuensi Tingkat Kecemasan Ibu Bersalin Sebelum Perlakuan

\begin{tabular}{lcc}
\hline $\begin{array}{l}\text { Tingkat } \\
\text { Kecemasan }\end{array}$ & $\begin{array}{c}\text { Frekuensi } \\
\text { (f) }\end{array}$ & $\begin{array}{c}\text { Persentase } \\
(\%)\end{array}$ \\
\hline Normal (0-9) & 8 & 40 \\
Ringan (10-13) & 9 & 45 \\
Sedang (14-20) & 2 & 10 \\
Berat (21-27) & 1 & 5 \\
Sangat berat & 0 & 0 \\
(>27) & & \\
\hline
\end{tabular}

Berdasarkan tabel 2 diatas menunjukkan bahwa dari 20 responden (100\%), sebelum diberikan aromaterapi lavender, tingkat kecemasan ibu bersalin adalah hampir setengahnya yaitu sebanyak sembilan responden (45\%) mengalami kecemasan ringan, sebagian kecil yaitu dua responden (10\%) mengalami kecemasan sedang dan sebagian kecil yaitu satu responden $(5 \%)$ mengalami kecemasan berat.

\section{Table 3. Distribusi Frekuensi Tingkat Kecemasan Ibu Bersalin Setelah Perlakuan}

\begin{tabular}{lcc}
\hline $\begin{array}{l}\text { Tingkat } \\
\text { Kecemasan }\end{array}$ & $\begin{array}{c}\text { Frekuensi } \\
(\mathbf{f})\end{array}$ & $\begin{array}{c}\text { Persentase } \\
(\%)\end{array}$ \\
\hline Normal (0-9) & 19 & 95 \\
Ringan (10-13) & 1 & 5 \\
Sedang (14-20) & 0 & 0 \\
Berat (21-27) & 0 & 0 \\
Sangat berat & 0 & 0 \\
$(>27)$ & &
\end{tabular}

Berdasarkan tabel 3 menunjukkan bahwa dari 20 responden (100\%), setelah diberikan aromaterapi lavender, hampir seluruhnya yaitu 19 responden (95\%) mengalami kondisi normal dan satu responden $(5 \%)$ mengalami kecemasan ringan.

Tabel 4. Hasil Analisis Bivariat (Paired TTest) Pretest dan Post Test Tingkat Kecemasan Ibu bersalin

\begin{tabular}{cc|c|c}
\multicolumn{4}{c}{ Paired Samples Correlations } \\
& N & Correlation & Sig. \\
\hline Pair 1 Cemas1 \& & 20 & .663 & .001 \\
Cemas2 & & & \\
\hline
\end{tabular}


Berdasarkan tabel 4 diatas menunjukkan bahwa bahwa p-value tingkat kecemasan ibu bersalin sebelum dan setelah diberikan aromaterapi lavender adalah 0.001 $(<0.05)$ maka dapat disimpulkan ada perbedaan yang bermakna antara tingkat kecemasan sebelum pemberian aromaterapi lavender dan setelah diberikan aromaterapi lavender.

\section{Berdasarkan hasil penelitian} menunjukkan bahwa karakteristik ibu memiliki peran yang penting terhadap persalinan karena memberikan pengaruh yang signifikan terhadap proses persalinan ibu seperti diuraikan oleh Nilda Yulita 2020 menunjukkan bahwa kecemasan dipengaruhi oleh beberapa faktor seperti usia ibu, tingkat pendidikan, dan paritas [16]. Berdasarkan hasil penelitian yang dilakukan oleh Asri, et al 2014 tentang hubungan karakteristik ibu hamil Trimester III dengan tingkat kecemasan ibu dalam menghadapi persalinan. Umur mempengaruhi seseorang dalam mengambil keputusan. Semakin cukup umur, tingkat kematangan dan kekuatan seseorang akan lebih matang dalam berfikir dan bekerja. Pendidikan dan pengetahuan seseorang saling berkaitan, ibu yang berpendidikan akan membuat keputusan yang benar dalam memperhatikan kesehatan keluarga dan diri sendiri, sedangkan paritas adalah keadaan wanita yang berkaitan dengan jumlah anak yang dilahirkan. Semakin banyak paritas semakin banyak pula pengalaman dan pengetahuannya sehingga mampu memberikan hasil yang lebih baik dan suatu pengalaman masa lalu yang mempengaruhi proses belajar [7].

Hasil penelitian ini didukung oleh hasil penelitian yang dilakukan oleh Igarashi Tahun 2015 bahwa terdapat efek relaksasi dari minyak esensial lavender yang mengandung linalyl acetate atau linalool. Linalyl acetate atau linalool yang dapat memperlancar keluarnya hormone serotonin yang tersumbat [6].

Hormon serotonin adalah salah satu zat kimia tubuh yang berperan untuk mengendalikan emosi dan suasana hati, bahkan dapat mengurangi gangguan kecemasan hingga depresi [6].

Sesuai dengan hasil penelitian yang dilakukan oleh Hosseini pada tahun 2016 di Madiun yang menunjukan bahwa, terdapat pengaruh pemberian aroma terapi lavender dalam mengurangi kecemasan persalinan [12]

Berdasarkan penelitian oleh Nila, dkk tahun 2019, dengan jumlah 15 responden didapatkan hasil rata - rata skor kecemasan menghadapi persalinan sebelum diberikan aromaterapi sebesar 18,07, kemudian turun menjadi 14,53 setelah diberikan aromaterapi lavender. Berdasarkan uji dependent t-test didapatkan hasil nilai $t$ hitung sebesar 16,412 dengan $p$-value $0,000<\alpha(0,05)$, ini menunjukkan bahwa ada perbedaan kecemasan menghadapi persalinan sebelum dan sesudah diberikan Aromaterapi Lavender [5].

Penelitian lainnya menunjukkan adanya pengaruh yang signifikan aromaterapi lavender sebelum dan setelah diberikan pada responden dengan hasil uji statistik paired t-test menunjukkan hasil rata - rata skor sebelum diberikan aromaterapi lavender adalah 20,8 sedangkan skor rata- rata setelah diberikan aromaterapi lavender adalah 17,6, maka hal ini menunjukkan adanya penurunan tingkat kecemasan dengan selisih 3,2 [17]

Berdasarkan hasil penelitian ini didapatkan bahwa aromaterapi lavender 
memiliki pengaruh yang signifikan terhadap tingkat kecemasan yang dialami oleh ibu bersalin pada masa pandemi covid-19.

\section{KESIMPULAN}

Dapat disimpulkan dari hasil penelitian yang dilakukan, ada pengaruh pemberian aromaterapi lavender terhadap kecemasan ibu bersalin pada masa pandemi covid-19.

\section{UCAPAN TERIMAKASIH}

Pada kesempatan ini, peneliti mengucapkan terimakasih kepada Yayasan Kartini Bali yang telah memberikan pendanaan dalam Hibah Penelitian Internal. Peneliti juga mengucapkan terimakasih kepada Puskesmas I Denpasar Timur yang telah memberikan iji dalam penelitian ini sehingga penelitian dapat selesai tepat waktu.

\section{DAFTAR PUSTAKA}

[1] Kementerian Kesehatan Republik Indonesia, Pedoman Bagi Ibu Hamil, Ibu Nifas Dan Bayi Baru Lahir. Jakarta: Sub Direktorat Kesehatan Maternal dan Neonatal Direktorat Kesehatan Keluarga, 2020.

[2] WHO, World Health Statistic 2019: Monitoring Health for the SDGs, Sustainable Development Goals. Geneva, 2019.

[3] A. R. Salsabilla, "Aromaterapi Lavender sebagai Penurun Tingkat Kecemasan Persalinan," J. Ilm. Kesehat. Sandi Husada, vol. 12, no. 2, pp. 761766, 2020, doi: 10.35816/jiskh.v12i2.407.

[4] R. D. Dila, F. Putra, and R. S. Fitriani Arifin, "Pengaruh aromaterapi lavender terhadap penurunan kecemasan ibu pre operasi sectio caesarea di rumah sakit bersalin," Caring Nurs. J., vol. 1, no. 2, pp. 51-56, 2017.

[5] G. Nila, W. Kristiningrum, and L. D.
Afriyani, "Efektivitas Aroma Terapi Lavender untuk Mengurangi Kecemasan Menghadapi Peralinan pada Ibu Hamil Trimester III di Wilayah Kerja Puskesmas Bergas," J. Holist. Heal. Sci., vol. 1, no. 1, 2019.

[6] D. Donelli, M. Antonelli, C. Bellinazzi, G. F. Gensini, and F. Firenzuoli, "Effects of Lavender on Anxiety: A Systematic Review and Meta-Analysis," Phytomedicine, vol. 65, no. September, 2019, doi: 10.1016/j.phymed.2019.153099.

[7] A. K, H. Bidjuni, and V. Kallo, "Hubungan Karakteristik Ibu Hamil Trimester Iii Dengan Tingkat Kecemasan Dalam Menghadapi Persalinan Di Poli Kia Puskesmas Tuminting," J. Keperawatan UNSRAT, vol. 2, no. 2, p. 110039, 2014.

[8] P. Wulandari, A. Sofitamia, and M. Kustriyani, "The Effect of Guided Imagery to The Level of Anxiety of Trimester III Pregnant Woman in The Working Area of Mijen Health Center in Semarang City," Media Keperawatan Indones., vol. 2, no. 1, p. 29, 2019, doi: 10.26714/mki.2.1.2019.29-37.

[9] D. Siallagan and D. Lestari, "Tingkat Kecemasan Menghadapi Persalinan Berdasarkan Status Kesehatan, Graviditas Dan Usia Di Wilayah Kerja Puskesmas Jombang," Indones. J. Midwifery, vol. 1, no. 2, pp. 104-110, 2018, doi: 10.35473/ijm.v1i2.101.

[10] R. Sinaga, K. Sianipar, and H. P. Tobing, "Penerapan Aromatherapi Terhadap Penurunan Kecemasan Ibu Inpartu," Community Engagem. Emerg. J., vol. 2, no. 1, pp. 132-140, 2021.

[11] M. Kazeminia et al., "The Effect of Lavender (Lavandula stoechas L.) on Reducing Labor Pain: A Systematic Review and Meta-Analysis," Evidencebased Complement. Altern. Med., vol. 2020, 2020, doi: $10.1155 / 2020 / 4384350$.

[12] S. A. Hosseini, A. Heydari, M. A. Vakili, S. Moghadam, and S. A. Tazyky, "Effect of Lavender Essence 
Inhalation on the Level of Anxiety and Blood Cortisol in Candidates for OpenHeart Surgery," Iran. J. Nurs. Midwifery Res., vol. 21, no. 4, pp. 397401, 2016, doi: 10.4103/17359066.185582.

[13] V. López, B. Nielsen, M. Solas, M. J. Ramírez, and A. K. Jäger, "Exploring Pharmacological Mechanisms of Lavender (Lavandula angustifolia) Essential Oil on Central Nervous System Targets," Front. Pharmacol., vol. 8, no. 280, pp. 1-8, 2017, doi: 10.3389/fphar.2017.00280.

[14] S. Mansour Lamadah, "The Effect of Aromatherapy Massage Using Lavender Oil on the Level of Pain and Anxiety During Labour Among Primigravida Women," Am. J. Nurs. Sci., vol. 5, no. 2, p. 37, 2016, doi: 10.11648/j.ajns.20160502.11.

[15] I. Mirazanah, B. T. Carolin, and S. Dinengsih, "Pengaruh Aromaterapi Lavender terhadap Kecemasan Ibu Bersalin," J. Kebidanan Malahayati, vol. 7, no. 4, pp. 785-792, 2021, doi: $10.33024 / \mathrm{jkm} . \mathrm{v} 7 \mathrm{i} 4.3856$.

[16] N. Y. Siregar et al., "Tingkat Kecemasan Ibu Hamil Trimester III dalam Menghadapi Persalinan," $J$. Bidan Cerdas, vol. 3, no. 1, pp. 18-24, 2021, doi: 10.33860/jbc.v3i1.131.

[17] K. N. Balqis, "Pengaruh aroma terapi lavender terhadap tingkat kecemasan ibu bersalin di BPM kota palembang tahun 2018," 2018, [Online]. Available: http://repository.binawan.ac.id/845/.

[1] Kementerian Kesehatan Republik Indonesia, Pedoman Bagi Ibu Hamil, Ibu Nifas Dan Bayi Baru Lahir. Jakarta: Sub Direktorat Kesehatan Maternal dan Neonatal Direktorat Kesehatan Keluarga, 2020.

[2] WHO, World Health Statistic 2019: Monitoring Health for the SDGs, Sustainable Development Goals. Geneva, 2019.

[3] A. R. Salsabilla, "Aromaterapi Lavender sebagai Penurun Tingkat Kecemasan Persalinan,” J. Ilm. Kesehat.
Sandi Husada, vol. 12, no. 2, pp. 761766, 2020, doi: 10.35816/jiskh.v12i2.407.

[4] R. D. Dila, F. Putra, and R. S. Fitriani Arifin, "Pengaruh aromaterapi lavender terhadap penurunan kecemasan ibu pre operasi sectio caesarea di rumah sakit bersalin," Caring Nurs. J., vol. 1, no. 2, pp. 51-56, 2017.

[5] G. Nila, W. Kristiningrum, and L. D. Afriyani, "Efektivitas Aroma Terapi Lavender untuk Mengurangi Kecemasan Menghadapi Peralinan pada Ibu Hamil Trimester III di Wilayah Kerja Puskesmas Bergas," J. Holist. Heal. Sci., vol. 1, no. 1, 2019.

[6] D. Donelli, M. Antonelli, C. Bellinazzi, G. F. Gensini, and F. Firenzuoli, "Effects of Lavender on Anxiety: A Systematic Review and Meta-Analysis," Phytomedicine, vol. 65, no. September, 2019 , doi: 10.1016/j.phymed.2019.153099.

[7] A. K, H. Bidjuni, and V. Kallo, "Hubungan Karakteristik Ibu Hamil Trimester Iii Dengan Tingkat Kecemasan Dalam Menghadapi Persalinan Di Poli Kia Puskesmas Tuminting," J. Keperawatan UNSRAT, vol. 2, no. 2, p. 110039, 2014.

[8] P. Wulandari, A. Sofitamia, and M. Kustriyani, "The Effect of Guided Imagery to The Level of Anxiety of Trimester III Pregnant Woman in The Working Area of Mijen Health Center in Semarang City," Media Keperawatan Indones., vol. 2, no. 1, p. 29, 2019, doi: 10.26714/mki.2.1.2019.29-37.

[9] D. Siallagan and D. Lestari, "Tingkat Kecemasan Menghadapi Persalinan Berdasarkan Status Kesehatan, Graviditas Dan Usia Di Wilayah Kerja Puskesmas Jombang," Indones. J. Midwifery, vol. 1, no. 2, pp. 104-110, 2018, doi: 10.35473/ijm.v1i2.101.

[10] R. Sinaga, K. Sianipar, and H. P. Tobing, "Penerapan Aromatherapi Terhadap Penurunan Kecemasan Ibu Inpartu," Community Engagem. Emerg. J., vol. 2, no. 1, pp. 132-140, 2021. 
[11] M. Kazeminia et al., "The Effect of Lavender (Lavandula stoechas L.) on Reducing Labor Pain: A Systematic Review and Meta-Analysis," Evidencebased Complement. Altern. Med., vol. 2020, 2020, doi: 10.1155/2020/4384350.

[12] S. A. Hosseini, A. Heydari, M. A. Vakili, S. Moghadam, and S. A. Tazyky, "Effect of Lavender Essence Inhalation on the Level of Anxiety and Blood Cortisol in Candidates for OpenHeart Surgery," Iran. J. Nurs. Midwifery Res., vol. 21, no. 4, pp. 397401, 2016, doi: 10.4103/17359066.185582.

[13] V. López, B. Nielsen, M. Solas, M. J. Ramírez, and A. K. Jäger, "Exploring Pharmacological Mechanisms of Lavender (Lavandula angustifolia) Essential Oil on Central Nervous System Targets," Front. Pharmacol., vol. 8 , no. 280 , pp. 1-8, 2017, doi: 10.3389/fphar.2017.00280.

[14] S. Mansour Lamadah, "The Effect of Aromatherapy Massage Using Lavender Oil on the Level of Pain and Anxiety During Labour Among Primigravida Women," Am. J. Nurs. Sci., vol. 5, no. 2 , p. 37, 2016, doi: 10.11648/j.ajns.20160502.11.

[15] I. Mirazanah, B. T. Carolin, and S. Dinengsih, "Pengaruh Aromaterapi Lavender terhadap Kecemasan Ibu Bersalin," J. Kebidanan Malahayati, vol. 7, no. 4, pp. 785-792, 2021, doi: 10.33024/jkm.v7i4.3856.

[16] N. Y. Siregar et al., "Tingkat Kecemasan Ibu Hamil Trimester III dalam Menghadapi Persalinan," $J$. Bidan Cerdas, vol. 3, no. 1, pp. 18-24, 2021, doi: 10.33860/jbc.v3i1.131.

[17] K. N. Balqis, "Pengaruh aroma terapi lavender terhadap tingkat kecemasan ibu bersalin di BPM kota palembang tahun 2018," 2018, [Online]. Available: http://repository.binawan.ac.id/845/. 